\title{
Perbedaan Kadar Glukosa Darah Puasa pada Akseptor Suntik Depo Medroksi Progesteron Asetat dengan Akseptor Pil Kombinasi di Puskesmas Lubuk Buaya Padang Tahun 2018
}

\author{
Fafelia Rozyka Meysetri ${ }^{1}$, Joserizal Serudji ${ }^{2}$, Meilinda Agus ${ }^{3}$
}

\begin{abstract}
Abstrak
Penggunaan kontrasepsi suntik depo medroxyprogesterone asetat yang mengandung hormon progesteron memiliki efek terhadap peningkatan kadar glukosa darah. Tujuan penelitian ini adalah menentukan perbedaan kadar glukosa darah puasa antara akseptor suntik depo medroxyprogesteron asetat dan akseptor Pil Kombinasi. Penelitian ini adalah studi observasional dengan desain cross sectional. Penelitian ini dilakukan di Puskesmas Lubuk Buaya Padang dan di Laboratorium Bagian Biokimia Fakultas Kedokteran Universitas Andalas dari bulan September 2018 sampai Januari 2019. Subjek penelitian ini terdiri dari dua kelompok yaitu akseptor suntik depo medroxyprogesteron asetat dan pil kombinasi yang masing-masing terdiri dari 33 sampel. Pemeriksaan kadar glukosa darah puasa dilakukan dengan metode kalorimetrik enzimatik (heksokinase). Data dianalisis menggunakan uji- $t$ dengan nilai $p<$ 0,05 dianggap bermakna secara statistik. Hasilnya didapatkan rerata kadar glukosa darah puasa antara akseptor Suntik Depo Medroxyprogesteron Asetat adalah 109,06 $\pm 3,54 \mathrm{mg} / \mathrm{dl}$ dan akseptor Pil Kombinasi adalah 101,89 $\pm 3,54$ dengan nilai $p=0,158$ yang berarti $p>0,05$. Simpulan penelitian ini adalah tidak terdapat perbedaan yang bermakna rerata kadar glukosa darah puasa antara akseptor KB suntik depo medroxyprogesteron asetat dengan akseptor pil kombinasi.
\end{abstract}

Kata Kunci: glukosa darah puasa, suntik depo medroxyprogesteron asetat, pil kombinasi

\begin{abstract}
The use of depo medroxyprogesterone asetat contraceptive injection containing the progesterone plays a role in increasing blood glucose levels. The objective of this study was to determine the differences between fasting blood glucose levels onn the acceptors of depot medroxyprogesterone acetate contraceptive injection and combination pill acceptors. This study was an observational study with cross sectional design. The research was conducted at the Lubuk Buaya Padang health center and at the Biochemical Laboratory of the Medical Faculty of Andalas University from September 2018 until January 2019. The subjects of this study were the acceptors of Depot Medroxy progesterone acetate injection and combination pills, consisting of 33 samples each. Fasting blood glucose level was examined by enzymatic calorimetric method (hexokinase). Data were analyzed by using the t-test which was considered statistically significant if $p$ value $<0.05$. The results showed that the mean fasting blood glucose levels between acceptors of the depot medroxyprogesterone acetate injection and the combination pill acceptor were 109.06 $\pm 3.54 \mathrm{mg} / \mathrm{dl}$ and $101.89 \pm 3.54 \mathrm{mg} / \mathrm{dl}$, respectively with $p$ value $=0.158$, which means $p>0.05$. This study concluded that there is no significant difference between mean fasting blood glucose levels between the acceptors of the depot medroxyprogesterone acetate injection and combination pill acceptors.
\end{abstract}

Keywords: fasting blood glucose, depot medroxyprogesterone acetate injections, combination pills

Affiliasi penulis: 1. Prodi S2 IImu Kebidanan Fakultas Kedokteran Universitas Andalas (FK Unand), 2. Bagian Kebidanan FK Unand/ RSUP Dr.M.Djamil, 3. Bagian Kebidanan Politeknik Kesehatan Kementerian Kesehatan Padang.
Korespondensi: Joserizal Serudji Email:jserudji@yahoo.co.id TELP:082147702920 


\section{PENDAHULUAN}

Tingginya laju pertumbuhan penduduk dan kurang seimbangnya penyebaran dan struktur umur penduduk masih merupakan masalah utama yang sedang dihadapi negara berkembang termasuk Indonesia. Jumlah penduduk yang besar tanpa diringi kualitas sumber daya manusia yang baik mempersulit usaha peningkatan dan pemerataan kesejahteraan rakyat. Semakin tinggi pertumbuhan penduduk semakin besar usaha yang diperlukan untuk mempertahankan tingkat kesejahteraan rakyat. ${ }^{1}$

Indonesia adalah negara dengan jumlah penduduk terbesar keempat di dunia (setelah Republik Rakyat Tiongkok, India dan Amerika Serikat). Berdasarkan hasil sensus penduduk tahun 2016, menunjukkan penduduk Indonesia berjumlah 254,7 juta jiwa. Menurut proyeksi pemerintah jumlah penduduk Indonesia akan terus bertambah dari 254,7 juta jiwa di tahun 2016 menjadi 271,1 juta orang di 2020 dan menjadi 305,6 juta orang di 2035. ${ }^{2}$

Badan Kependudukan dan Keluarga Berencana Negara ikut serta dalam memperkuat pelaksanaan pembangunan kependudukan dengan upaya pengendalian kuantitas dan peningkatan kualitas penduduk dan mengarahkan persebaran penduduk. Pembangunan kependudukan juga merupakan upaya untuk mewujudkan keserasian kondisi yang berhubungan dengan perubahan keadaan penduduk yang dapat berpengaruh dan dipengaruhi oleh keberhasilan pembangunan berkelanjutan. $^{3}$

Upaya pengendalian pertumbuhan penduduk dilakukan melalui Program Kependudukan, Keluarga Berencana dan Pembangunan Keluarga dalam rangka mewujudkan norma keluarga kecil, bahagia, dan sejahtera, serta diharapkan juga dapat memberikan kontribusi terhadap perubahan kuantitas penduduk yang ditandai dengan perubahan jumlah, struktur, komposisi dan persebaran penduduk yang seimbang sesuai dengan daya dukung dan daya tampung lingkungan hidup. ${ }^{3}$

Salah satu program untuk menekan angka pertumbuhan penduduk adalah dengan adanya program Keluarga Berencana (KB). ${ }^{4}$ Keluarga Berencana adalah usaha untuk menjarangkan atau merencanakan jumlah dan jarak kehamilan dengan memakai kontrasepsi. Pemberian layanan keluarga berencana hendaknya dipandang sebagai suatu layanan kesehatan reproduksi wanita dalam konteks yang lebih luas. Layanan keluarga berencana berkualitas tinggi mencakup penyediaan pilihan alat kontrasepsi yang aman dan sesuai bagi wanita. ${ }^{5}$

Kontrasepsi yang tersedia saat ini berupa metode kontasepsi hormonal dan non hormonal, dimana kontrasepsi hormonal merupakan salah satu metode kontrasepsi yang mempunyai efektivitas tinggi. Hormon yang terkandung dalam kontrasepsi hormonal ini adalah hormon sintetik estrogen dan progesteron. ${ }^{6}$ Metode kontrasepsi hormonal ini terdiri dari pil, suntik dan implant. Kontrasepsi hormonal banyak digunakan karena relatif praktis dan tidak mengurangi kenyamanan dibanding metode lainnya seperti kondom. Penggunaan kontrasepsi hormonal seperti suntik dan pil kombinasi terdapat efek samping yang paling mengkhawatirkan dari penggunaan kontrasepsi tersebut yaitu gangguan kadar gula darah. Diduga hormon yang digunakan dapat mempengaruhi kerja insulin dalam metabolisme gula sehingga meningkatkan kadar gula darah. ${ }^{7}$

Kadar glukosa darah merupakan suatu indikator dalam diagnosis Diabetes Melitus (DM). Diabetes melitus adalah penyakit metabolisme yang merupakan suatu kumpulan gejala yang timbul pada seseorang karena adanya peningkatan glukosa darah di atas nilai normal. ${ }^{8}$

Hasil data survei awal diketahui bahwa pemakaian kontrasepsi suntik oleh peserta KB aktif selama tahun 2017 di Kota Padang sebanyak 56.894 orang. Pemakaian kontrasepsi Pil KB kombinasi oleh peserta KB aktif sebanyak 23.543 orang. Persentase peserta KB aktif paling tinggi terdapat di wilayah kerja puskesmas Lubuk Buaya Padang yang menggunakan kontrasepsi suntik yaitu 9,57\% dan kontrasepsi Pil KB kombinasi yaitu $11,7 \%{ }^{9}$

\section{METODE}

Penelitian ini merupakan studi observasional dengan menggunakan pendekatan cross-sectional, yang dilakukan di Puskesmas Lubuk Buaya Padang. Sampel yang digunakan adalah sebanyak 66 orang, masing-masing sampel terdiri dari 33 akseptor Suntik Depo Medroxyprogesterone Asetat (DMPA) dan 33 
akseptor pil kombinasi yang memenuhi kriteria inklusi dan eksklusi. Sampel ditentukan dengan sistematik consecutive sampling. Data terlebih dahulu diuji dengan uji Kolmogorov-smirnov maka diperoleh data berdistribusi normal (nilai $0>0,05$ ), kemudian dilanjutkan uji $\mathrm{t}$ tidak berpasangan. Perbedaan bermakna secara statistik apabila nilai $p<0,05$.

HASIL

Penelitian ini telah dilakukan terhadap 66 responden yang memenuhi kriteria inklusi dan eksklusi terdiri dari dua kelompok yaitu 33 akseptor suntik Depo Medroxyprogesterone Asetat dan 33 akseptor Pil Kombinasi.

Tabel 1. Karakteristik responden penelitian

\begin{tabular}{|c|c|c|c|}
\hline \multirow{3}{*}{ Karakteristik } & Suntik & Pil & \multirow{3}{*}{ p } \\
\hline & DMPA & Kombinasi & \\
\hline & $\begin{array}{c}\text { rerata } \pm S D \\
\text { (tahun) }\end{array}$ & $\begin{array}{c}\text { rerata } \pm \text { SD } \\
\text { (tahun) }\end{array}$ & \\
\hline Umur & $36,97 \pm 1,16$ & $39,24 \pm 1,13$ & 0,166 \\
\hline
\end{tabular}

Tabel 1. menunjukkan bahwa rerata umur responden yang menggunakan suntik depo medroxy progesterone Asetat yaitu 36,97 $\pm 1,16$ tahun dan pil kombinasi yaitu 39,24 $\pm 1,13$ tahun. Hasil uji t tidak berpasangan menunjukkan bahwa nilai $p=0,166$ ( $>0,05)$. Hal ini menunjukkan bahwa secara statistik tidak ada perbedaan yang bermakna antara kedua kelompok.

Tabel 2. Lama Pemakaian alat kontrasepsi responden

\begin{tabular}{lccc}
\hline Karakteristik & $\begin{array}{c}\text { Suntik } \\
\text { DMPA }\end{array}$ & $\begin{array}{c}\text { Pombinasi } \\
\text { Kom }\end{array}$ & $\mathbf{p}$ \\
\cline { 2 - 3 } & $\begin{array}{c}\text { rerata } \pm S D \\
\text { (tahun) }\end{array}$ & $\begin{array}{c}\text { rerata } \pm \text { SD } \\
\text { (tahun) }\end{array}$ & \\
\hline $\begin{array}{l}\text { Lama } \\
\text { Pemakaian }\end{array}$ & $6,02 \pm 0,71$ & $6,06 \pm 0,58$ & 0,961 \\
\hline
\end{tabular}

Tabel 2 menunjukkan bahwa rata-rata lama pemakaian kontrasepsi sudah setara antara pengguna suntik depo medroxyprogesterone asetat yaitu 6,02 \pm 0,71 tahun dan pil kombinasi yaitu 6,06 $\pm 0,58$ tahun. Hasil uji t tidak berpasangan menunjukkan bahwa nilai $P=0,961 \quad(p>0,05)$ dan hal ini juga menunjukkan bahwa secara statistik tidak ada perbedaan yang bermakna antara kedua kelompok.

Tabel 3. Perbedaan kadar glukosa darah puasa pada akseptor suntik DMPA dengan akseptor pil kombinasi

\begin{tabular}{ccc}
\hline Kontrasepsi & $\begin{array}{c}\text { Kadar glukosa darah } \\
\text { puasa Rerata } \pm \text { SD } \\
(\mathbf{m g} / \mathbf{d l})\end{array}$ & p \\
\hline DMPA & $109,061 \pm 3,541$ & 0,158 \\
Pil Kombinasi & $101,897 \pm 3,546$ & \\
\hline
\end{tabular}

Tabel 3 menunjukkan bahwa rerata kadar glukosa darah puasa pada akseptor suntik depo medroxyprogesterone asetat lebih tinggi yaitu 109,06 $\pm 3,54 \mathrm{mg} / \mathrm{dl}$ daripada rerata kadar glukosa darah puasa pada akseptor Pil Kombinasi yaitu 101,89 \pm 3,54 mg/dl. Hasil uji t tidak berpasangan didapatkan nilai $p=0,158 \quad(p>0,05)$, sehingga dapat dinyatakan bahwa tidak terdapat perbedaan yang bermakna rerata kadar glukosa darah puasa pada akseptor Suntik Depo

\section{PEMBAHASAN}

Peningkatan kadar glukosa darah puasa juga dipengaruhi oleh umur, semakin tua umur seseorang maka semakin meningkatkan kadar glukosa darah puasa, meskipun pada hasil yang didapatkan tidak terdapat perbedaan dan kemaknaan tetapi secara kuantitas rerata umur pada pemakai pil kombinasi lebih tinggi dari pada suntik, kemungkinan menjadi faktor yang menyebabkan tingginya kadar glukosa darah puasa pada pil kombinasi. Dalam penelitian ini peneliti tidak memberikan batasan umur maksimal, sehingga didapatkan rerata umur ibu yang menggunakan kontrasepsi bukan termasuk umur yang reproduktif lagi.

Umur berpengaruh terhadap kadar glukosa darah dimana resiko diabetes mellitus akan meningkat sejalan bertambahnya usia, terutama setelah usia 40 tahun karena jumlah sel-sel beta didalam pankreas yang memproduksi insulin menurun seiring bertambahnya umur. Penurunan produksi insulin mengakibatkan berkurangnya jumlah glukosa yang masuk ke dalam sel, sehingga glukosa akan tetap berada dalam pembuluh darah dan menyebabkan kadar glukosa darah meningkat. ${ }^{10}$ 
Hasil penelitian ini sesuai dengan penelitian sebelumnya oleh Panggayuh (2014) yang menyatakan bahwa tidak terdapat perbedaan kadar glukosa darah antara akseptor suntik kombinasi progesteron dan estrogen dengan akseptor suntik depo medroxyprogesterone asetat. Pada kedua jenis akseptor suntik hormonal tersebut menunjukkan perubahan kadar glukosa dalam kriteria gangguan toleransi glukosa. Gangguan toleransi glukosa tersebut kemungkinan diakibatkan oleh mekanisme kerja dari progesteron dan estrogen sintetik dari kontrasepsi hormonal yang mempengaruhi resistensi insulin, jumlah dan afinitas reseptor insulin terhadap glukosa dan peningkatan jumlah kortisol bebas. Pada penelitian ini tidak dilakukan penapisan terhadap riwayat kesehatan atau penyakit kepada responden. ${ }^{11}$

Studi ini tidak sejalan dengan penelitian yang dilakukan oleh Barenson et al, yang melakukan penelitian mengenai pengaruh pemakaian dua metode kontrasepsi hormonal yang mengandung 20 mikrogram etinil estradiol dan 0,15 mg desogestrel terhadap kadar glukosa dan insulin serum serta setiap perubahan prediktor yang diamati. Sampel dalam penelitian Barenson et al adalah wanita dari ras white, black dan Hispanic dengan umur 16-33 tahun. Penelitian tersebut adalah penelitian kuantitatif dengan longitudinal study. Pemeriksaan kadar glukosa dan serum insulin menggunakan pemeriksaan serum insulin assay (Access Immunoassay System) dan serum glucose assay (Vitros 5,1 FS Chemistry System). ${ }^{12}$ Hasil penelitian ini adalah pada pengguna kontrasepsi DMPA mengalami sedikit peningkatan glukosa dan insulin yang lebih besar dibandingkan dengan pengguna kontrasepsi nonhormonal. Penggunaan kontrasepsi DMPA mengalami peningkatan pada glukosa serum $(2 \mathrm{mg} / \mathrm{dl}$ pada enam bulan sampai $3 \mathrm{mg} / \mathrm{dl}$ pada tiga puluh bulan) yang diamati pada 30 bulan pertama tetapi setelah itu tidak mengalami peningkatan. Selain itu juga terjadi peningkatan insulin dan glukosa yang lebih tinggi pada pengguna DMPA dengan obesitas dan Overweight daripada pengguna DMPA dengan berat badan normal.

Pada wanita pengguna kontrasepsi hormonal seperti suntik DMPA dan Pil kombinasi dapat timbul beberapa efek samping yang merugikan pemakainya yang salah satunya adalah peningkatan kadar glukosa dalam darah, sebagai akibat dari toleransi glukosa darah yang menurun. Formulasi kontrasepsi suntik DMPA dengan progesterone dosis tinggi menunjukkan tes toleransi glukosa yang abnormal pada pemakainya, dengan tingkat insulin yang meningkat pada rata-rata pasien. Efeknya pada metabolisme karbohidrat akan menurunkan toleransi glukosa. Progesterone juga dapat menurunkan kecepatan absorbsi karbohidrat dari sistem pencernaan makanan. Hal ini terkait dengan potensi androgenik dari progesteron, serta tinggi rendahnya dosis progesteron. ${ }^{13}$

Kontrasepsi suntik DMPA yang mengandung hormon progesteron berperan dalam mencegah terjadinya ovulasi dengan mempengaruhi hipofisis anterior yang menghasilkan FSH dan LH. FSH berfungsi untuk merangsang kematangan folikel degraaf dalam ovarium dalam mensekresikan estrogen. Dengan adanya pemberian DMPA maka akan menyebabkan lonjakan progesteron yang cukup tinggi sehingga kerja LH menurun, estrogen tidak dapat disekresikan dengan cukup oleh folikel. ${ }^{14}$

Lonjakan hormon progesteron berpengaruh terhadap metabolisme karbohidrat berupa pergeseran kortisol oleh progestin dari ikatannya dengan globulin di dalam sirkulasi yang menyebabkan peningkatan kadar kortisol bebas, melalui mekanisme kompetisi ikatan dengan globulin (transkotin), dimana globulin mempunyai afinitas yang lebih tinggi untuk berikatan dengan progesterone dibandingkan dengan kortisol. ${ }^{14}$ Kortisol merupakan glukokortikoid utama pada manusia. Kortisol memiliki efek dalam tubuh antara lain dalam metabolisme glukosa (gluconeogenesis) yang meningkatkan kadar glukosa darah. ${ }^{15}$

Pil kombinasi merupakan pil kontrasepsi yang berisi hormon sintesis estrogen dan progesterone. ${ }^{1}$ Estrogen bekerja primer untuk membantu pengaturan hormon realizing factors di hipotalamus, membantu pertumbuhan dan pematangan ovum di dalam ovarium dan merangsang perkembangan endometrium. Progesterone bekerja primer menekan dan melawan isyarat-isyarat dari hipotalamus dan mencegah pelepasan ovum yang terlalu dini/premature dari ovarium serta juga merangsang perkembangan dari endometrium. ${ }^{16}$ 
Komponen progesteron yang digunakan sebagai bahan kontrasepsi oral kombinasi, telah mengalami perubahan sejak pertama kali ditemukan. Diakui bahwa struktur kimia itu dapat memberikan efek yang merugikan maupun yang menguntungkan. Pemikiran tersebut diatas menarik minat beberapa ahli untuk melakukan beberapa riset yang hasilnya ternyata masih menunjukkan adanya beberapa perbedaan pendapat. Namun, sebagian besar dari hasil riset tersebut menyatakan bahwa, obat-obat kontrasepsi oral generasi baru sebagian besar tidak menunjukkann adanya gangguan pada metabolisme karbohidrat, walaupunn sebagian kecil ada gangguan, sifatnya hanya ringan saja tidak sampai menunjukkan adanya kemaknaan klinis. ${ }^{17}$

Kontrasepsi oral yang hanya mengandung estrogen saja, tidak memiliki efek merugikan pada metabolisme glukosa, tetapi yang mengandung progesterone menunjukkan antagonisme dengan insulin. Formulasi kontrasepsi oral dengan progesteron dosis tinggi menunjukkan tes toleransi glukosa yang abnormal pada pemakainya, dengan tingkat insulin yang meningkat pada rerata pasien. Progesteron juga dapat menurunkan kecepatan absorbs karbohidrat dari system pencernaan makanan. Hal tersebut diatas terkait dengan potensi androgenik dari progesteron, serta tinggi rendahnya dosis progesteron. ${ }^{18}$

\section{SIMPULAN}

Tidak terdapat perbedaan kadar glukosa darah puasa pada akseptor suntik depo medroxyprogesteron asetat dengan akseptor pil kombinasi.

\section{UCAPAN TERIMA KASIH}

Terima kasih kepada tenaga kesehatan terutama Bidan di Puskesmas Lubuk Buaya Padang atas fasilitas yang telah diberikan. Serta petugas di Laboratorium Biokimia Fakultas Kedokteran Universitas Andalas Padang atas sarana dan prasarana yang diberikan kepada peneliti sebagai tempat penelitian.

\section{DAFTAR PUSTAKA}

1. Handayani S. Buku ajar pelayanan keluarga berencana. Yogyakarta: Pustaka Rihama; 2010.hlm.17

2. Bappenas. Pembangunan daerah dalam angka tahun 2013. Bidang Pengembangan Regional dan Otonomi Daerah. Jakarta: Bappenas; 2013

3. Badan Kependudukan dan Keluarga Berencana Negara (BKKBN). Review program KKBPK tahun 2017. Provinsi Sumatera Barat: BKKBN.hlm.96.

4. Badan Kependudukan dan Keluarga Berencana Negara (BKKBN). Buku panduan praktis pelayanan kontrasepsi. Jakarta: PT Bina Pustaka Sarwono Prawirohardjo; 2010.hlm.8-15.

5. Kementerian Kesehatan Republik Indonesia (Kemenkes RI). Pusat Data dan informasi kementerian kesehatan $\mathrm{RI}$ situasi dan analisis keluarga berencana. Jakarta: Kementerian Kesehatan RI; 2014

6. Sulistyawati A. Pelayanan keluarga berencana. Jakarta: Salemba Medika; 2011.hlm.5-7.

7. Pramudiarja U. Ukuran tubuh manusia 100 tahun mendatang bakal menyusut. 2011 [diakses 12 Desember 2017]: Tersedia dari: http://www. detikhealth.com/read/2011/06/16/092859/1661459/ $763 /$.

8. Kementerian Kesehatan RI (Kemenkes RI). Riset kesehatan dasar (Riskesdas). Jakarta: Balitbang Kemenkes RI; 2013

9. Dinas Kesehatan Kota Padang. Profil kesehatan kota Padang 2017. Padang: Dinas Kesehatan Kota Padang; 2017.

10. Ramaiah. Diabetes. cara mengetahui gejala diabetes dan mendeteksi sejak dini. Jakarta: PT Buana Ilmu Populer ; 2009

11. Panggayuh $A$. Keluarga berencana. keterampilan dasar kebidanan; 2014. Modul II. hlm.35-42 (diakses 16 april 2019). Tersedia dari: https://docplayer.info/31638923-Pemeriksaandiagnostik-ardi-panggayuh-s-kp-m-kes.htm

12. Barenson $A B$, Van Den Berg $P$, Williams KJ. Effect of injectable and oral contraceptives on glucose and insulin levels. Obstetrics \& Gynecology; 2011.hlm.41-7. 
13. Ludickea F. Randomized controlled study of the influence of two low estrogen dose oral contraceptives containing gestodene or desogestrel on carbohydrate metabolism. Contraception. 2002;66(6):411-5.

14. Speroff L, Fritz MA. Hormone biosynthesis, metabolism and mechanism of action.in clinical gynecologic endocrinology and infertility. Lippincot Williams \& Wilkins. Philadelphia; 2005. Vol-7. hlm.87-94.

15. Rahardja K. Obat-obat penting, khasiat, penggunaan dan efek samping. Jakarta:

Departemen Kesehatan Republik Indonesia; 2007 Edisi V. page:693-708

16. Hartanto $H$. Keluarga berencana dan kontrasepsi. Jakarta: Pustaka Sinar Harapan; 2010.hlm.23-5.

17. Bende DA, Mayes PA. Gluconeogenesis \& control of blood glucose. Jakarta: Penerbit Buku Kedokteran EGC; 2009.hlm.112.

18. Chrousos, GP. The gonadal hormone \& inhibitors; on Katzung basic and clinical pharmacology. The McGraw-Hill Companies; 2007.hlm.664-71. 